Article

\title{
Impact of Rye Inclusion in Diets for Broilers on Performance, Litter Quality, Foot Pad Health, Digesta Viscosity, Organ Traits and Intestinal Morphology
}

\author{
Amr Abd El-Wahab ${ }^{1, \dagger}{ }^{\dagger}$ Jan Berend Lingens ${ }^{2,+}$, Bussarakam Chuppava ${ }^{2}$, Marwa F. E. Ahmed ${ }^{3}$, \\ Ahmed Osman ${ }^{2}$, Marion Langeheine ${ }^{4}$, Ralph Brehm ${ }^{4}{ }^{\circledR}$, Venja Taube ${ }^{5}$, Richard Grone ${ }^{6}$, \\ Andreas von Felde ${ }^{6}$, Josef Kamphues ${ }^{2}$ and Christian Visscher ${ }^{2, *}$ (1) \\ 1 Department of Nutrition and Nutritional Deficiency Diseases, Faculty of Veterinary Medicine, Mansoura \\ University, Mansoura 35516, Egypt; amrwahab5@mans.edu.eg \\ 2 Institute for Animal Nutrition, University of Veterinary Medicine Hannover, Foundation, \\ Bischofsholer Damm 15, D-30173 Hannover, Germany; jan.berend.lingens@tiho-hannover.de (J.B.L.); \\ bussarakam.chuppava@tiho-hannover.de (B.C.); ahmed.saeed.osman@tiho-hannover.de (A.O.); \\ josef.kamphues@tiho-hannover.de (J.K.) \\ 3 Department of Hygiene and Zoonoses, Faculty of Veterinary Medicine, Mansoura University, \\ Mansoura 35516, Egypt; marwafawzy@mans.edu.eg \\ 4 Institute for Anatomy, University of Veterinary Medicine Hannover, Foundation, Bischofsholer Damm 15, \\ D-30173 Hannover, Germany; marion.langeheine@tiho-hannover.de (M.L.); \\ ralph.brehm@tiho-hannover.de (R.B.) \\ 5 BEST 3 Geflügelernährung GmbH, Ringstrasse 16, D-27239 Twistringen, Germany; v.taube@best-3.de \\ 6 KWS LOCHOW GmbH, Ferdinand von Lochowstrasse 5, D-29303 Bergen, Germany; \\ richard.grone@kws.com (R.G.); andreas.vonfelde@kws.com (A.v.F.) \\ * Correspondence: christian.visscher@tiho-hannover.de \\ + These authors contributed equally to this work.
}

Received: 30 August 2020; Accepted: 17 September 2020; Published: 19 September 2020

\begin{abstract}
Rye could offer diverse benefits in terms of sustainability if it could replace parts of the main cereals, corn and wheat, in broiler diets. A total of 256 broilers, Ross 308, were randomly allocated into 32 pens. From day 14 till day 42, the birds were divided into four feeding groups (eight replicates each). The control group received a conventional finisher diet "control", whereas in the other groups, a pelleted supplementary feed was offered (SFI to corn and SFII to rye), to which crushed corn (SFI-Corn) or squashed rye (SFII-Rye) was added. The fourth group received a mixture of $50 \%$ SFI-Corn and 50\% SFII-Rye. The cereal level was increased weekly $(5 \%, 10 \%, 20 \%, 30 \%)$ at the expense of the supplementary feeds. No significant effects were observed for body weight at d 42 and excreta viscosity between all groups. Overall, foot pad health was excellent. Compared to the control group, birds fed SFI-Corn displayed a significant increase in gizzard relative weight, whereas, in contrast to all other groups, ileal villus height was significantly lower. In conclusion, feeding SFI-Corn or SFII-Rye diets had no negative influences on performance, litter quality and digesta viscosity, whereas SFI-Corn partially affected ileal morphology.
\end{abstract}

Keywords: diet; poultry; sustainability; growth; gut health

\section{Introduction}

As poultry, defined as domesticated birds, provide food security, protein supply and human livelihood, they are considered beneficial animals worldwide [1]. To ensure that it continues to make positive and sustainable contributions to a stable human food supply, it is essential to maximise the efficacy of all feedstuffs/products that highlight the links between poultry production, nutrition 
and sustainable ecosystem services [2]. Feed constitutes about $50-70 \%$ of the total costs in animal production. Consequently the constant increase in feed ingredient costs force producers to refocus on how to use their resources in feeding efficiency [3]. Moreover, according to the International Feed Industry Federation [4], it is forecast that by 2050, the livestock production will double. Thus, there is a major need to meet the nutritive requirements of poultry by detecting suitable alternatives to the conventional feed sources.

Secale is a genus of grasses in the Triticeae tribe, with the most known member of Secale being rye (S. cereale L.) which is widely grown as a grain and as a forage crop [5]. Rye is characterised by high yield production, good resistance to fungal diseases and bad weather conditions (low temperature and drought), and a high tolerance to irregular $\mathrm{pH}$ in the soil [6]. For many decades, its acreage has decreased, with corn, wheat and triticale becoming the more preferred alternatives. Undoubtedly, the interest in rye has increased, particularly in recent years [6], and could be interesting in terms of the sustainability debate. However, the use of rye for intensive poultry production has been limited to date [7] as it has some specific properties. The reason for its limitation is its high concentration of non-starch polysaccharides (NSP) amounting to about $152 \mathrm{~g}$ per $\mathrm{kg}$ of dry matter (DM), mainly highly branched arabinoxylans [8]. Arabinoxylans are complex cell wall polysaccharides amounting to about $85 \mathrm{~g} / \mathrm{kg}$ DM rye [9]. It is well known that arabinoxylans enhance digesta viscosity [10], which might lead to a slower passage rate and impaired absorption of nutrients which, in turn, depress growth [11,12]. Another negative effect of viscosity is that it has the ability to hold water in the digesta, producing sticky droppings and increased moisture of the litter [13,14]. Furthermore, increased intestinal viscosity might change the morphology of the ileal villi $[10,15]$. Owing to a lack of endogenous enzymes that degrade dietary fibres, including soluble NSP, intestinal viscosity increases, which slows down the migration and absorption of nutrients [7]. A few years ago, new competitive varieties of hybrid rye became available on the market $[16,17]$.

Both the physical form of the grain and feeding whole grain to broilers have attracted considerable attention in recent years. According to Hetland et al. [18] and Svihus [19], structural components in broiler diets such as whole grains are thought to stimulate the gizzard development (activity and size), digestive functions and digesta retention time of the GIT. Birds have been found to prefer coarse feed particles, which are thought to be responsible for a developed gizzard, ensuring a complete grinding and a well-regulated digesta flow, secretion of digestive juices as well as controlling gut motility [20,21]. Thus, nutritionists have discussed the effects of whole/crushed grain feeding or diet dilution at various growth stages in broilers on performance and a reduction in feed costs. Adding intact grain as wheat (feed particle size) with pelleted diets is currently the standard procedure used in the large poultry fattening sector with a positive effect on intestinal health [22]. Thus, it could be an option to reduce the negative effects of feeding rye. Additionally, the extraordinary high amounts of fructans $(40-60 \mathrm{~g} / \mathrm{kg}$ $\mathrm{DM}$ ) and arabinoxylans (90-120 $\mathrm{g} / \mathrm{kg} \mathrm{DM}$ ) in rye, which can only be degraded by microorganisms, open chances for modulating the fermentation pattern towards a forced formation of butyrate, which is considered a favoured energy and nutrient supply of the intestinal mucosa [23]. Therefore, it would be cost-beneficial to incorporate them into the poultry diet at a higher level.

A low prevalence and severity of foot pad dermatitis (FPD) are highly desirable regarding the health of birds and animal welfare. The high concentrations of NSP in plant sources such as wheat and other grains affect the digestive process (viscosity) and litter quality [24]. Nevertheless, feeding measures and housing conditions are as important as managing the quality of litter, especially its moisture content (the key factor) with regards to reducing the incidence and severity of FPD [25]. Therefore, against this background, the objectives of this experiment were to test whether rye could replace corn or wheat and to estimate the effect of upper inclusion levels of crushed corn or squashed rye of up to $30 \%$ in broilers on growth performance, litter quality, foot pad health, digesta viscosity, organ traits and intestinal morphology. 


\section{Materials and Methods}

Animal experiments were carried out in accordance with German regulations. These animal experiments required no notification or approval in accordance with the Animal Protection Act ( $\S 7$, paragraph 2, sentence 3). The animals were killed in accordance with $\S 4$, paragraph 3 of the Animal Protection Act, exclusively to use their organs or tissues for scientific purposes. A percussive blow to the head was used as anaesthesia, or rather, the stunning method, in accordance with Annex I of Council Regulation (EC) No. 1099/2009, Chapter I, Methods, Table-Mechanical methods, No. 6. After bleeding the animals, organs and tissues were removed for further analysis. The experiments were approved by the Animal Welfare Officer of the University of Veterinary Medicine Hannover, Germany (reference: TiHo-T-2019-21).

\subsection{Birds and Housing}

Day-old broilers of Ross 308 genetics of both sexes as hatched were obtained from a commercial hatchery and were randomly allocated into four pens for the first week of life and fed a commercial starter diet. From d 7 of life, 256 broilers were moved into the experimental unit and were divided randomly into four feeding groups (with eight replicates each and eight birds/pen) and were fed one identical commercial grower diet. The surface area of the pens was $1.20 \times 0.80 \mathrm{~m}$, and each pen contained a feeding trough and hanging nipple drinker (J. Hemel Brutgeräte GmbH \& Co. KG, Am Buschbach 20, 33,415 Verl, Germany). To maintain a good water quality, sodium hypochlorite was added to the water. The stocking density was about $27 \mathrm{~kg} / \mathrm{m}^{2}$ (usable area) at the end of the trial ( $\mathrm{d} 42$ of life) per pen. Wood shavings (GOLDSPAN ${ }^{\circledR}$, Goldspan GmbH and Co. KG, Goldenstedt, Germany) were used as bedding material ( 1 kg/pen). The broiler unit was continuously illuminated during the first three days. From d 4 onwards, the broiler house was illuminated according to the schedule 18L:6D with dimmed night lighting. The temperature inside the experimental room was increased to $36{ }^{\circ} \mathrm{C}$ before arrival of the broilers; thereafter, the temperature was gradually decreased to $20^{\circ} \mathrm{C}$ until the end of the experiment.

\subsection{Diets}

The diets and water were provided ad libitum. The broilers received a standard commercial starter $(0$ to $6 \mathrm{~d}$ ) and grower ( 7 to $13 \mathrm{~d}$ ) pelleted diets. The feeding trial ran during the finisher period (day 14 to beginning of day 42), whereas different experimental diets were provided (Table 1). One finisher diet (control diet) based on wheat and soybean meal was used for the control group throughout the trial. In order to maximise the comparability of the finisher diet, two special pelleted supplementary feeds (Best 3 Geflügelernährung GmbH, Twistringen, Germany) were produced. Each consisted of a pelleted supplementary feed (supplementary feed to corn (SFI), supplementary feed to rye (SFII), to which increasing amounts of crushed corn (SFI-Corn) or squashed rye (SFII-Rye) were added. The fourth group received a mixture of 50\% SFI-Corn and 50\% SFII-Rye (Mixed). Every week, the percentage of the crushed corn or squashed rye was increased $(5 \%, 10 \%, 20 \%$ and $30 \%$, respectively; Table 1$)$. The crushed corn or squashed rye were processed by using a Sommer Grainmaster 1100 (Egon Sommer Maschinenbau GmbH \& Co. KG, Osnabrück, Germany). Briefly, it has two-roller mills that are designed for the processing of highly abrasive hard grain varieties. The crushing is adjusted to be as narrow as possible. Therefore, the adjustment roller was set very tight. The name of rye was KWS Trebiano (KWS LOCHOW GmbH, Bergen, Germany). With the exception of the control diet, the other complete feeds were prepared weekly by manually mixing the required amount of supplementary feed (e.g., 95\% in 3rd week) with the specific percentage of crushed corn (5\% in 3rd week). Thus, three experimental diets were formulated and mixed every week till the end of the trial (SFI-Corn, SFII-Rye and Mixed), in addition to one finisher diet that was used for the control group. 
Table 1. Experimental design concerning groups and feeding phases.

\begin{tabular}{|c|c|c|c|c|c|c|c|c|}
\hline $\begin{array}{c}\text { Week of } \\
\text { Life }\end{array}$ & Group & Starter & Grower & Finisher & SFI $^{1}$ & SFII $^{2}$ & $\begin{array}{c}\text { Crushed } \\
\text { Corn }\end{array}$ & $\begin{array}{c}\text { Squashed } \\
\text { Rye }\end{array}$ \\
\hline 1 & \multirow{2}{*}{ All groups } & $100 \%$ & & & & & & \\
\hline 2 & & & $100 \%$ & & & & & \\
\hline \multirow{4}{*}{3} & Control & & & $100 \%$ & & & & \\
\hline & SFI-Corn & & & & $95 \%$ & & $5 \%$ & \\
\hline & SFII-Rye & & & & & $95 \%$ & & $5 \%$ \\
\hline & Mixed & & & & $47.5 \%$ & $47.5 \%$ & $2.5 \%$ & $2.5 \%$ \\
\hline \multirow{4}{*}{4} & Control & & & $100 \%$ & & & & \\
\hline & SFI-Corn & & & & $90 \%$ & & $10 \%$ & \\
\hline & SFII-Rye & & & & & $90 \%$ & & $10 \%$ \\
\hline & Mixed & & & & $45 \%$ & $45 \%$ & $5 \%$ & $5 \%$ \\
\hline \multirow{4}{*}{5} & Control & & & $100 \%$ & & & & \\
\hline & SFI-Corn & & & & $80 \%$ & & $20 \%$ & \\
\hline & SFII-Rye & & & & & $80 \%$ & & $20 \%$ \\
\hline & Mixed & & & & $40 \%$ & $40 \%$ & $10 \%$ & $10 \%$ \\
\hline \multirow{4}{*}{6} & Control & & & $100 \%$ & & & & \\
\hline & SFI-Corn & & & & $70 \%$ & & $30 \%$ & \\
\hline & SFII-Rye & & & & & $70 \%$ & & $30 \%$ \\
\hline & Mixed & & & & $35 \%$ & $35 \%$ & $15 \%$ & $15 \%$ \\
\hline
\end{tabular}

\subsection{Feed Analysis and Feed Composition}

The chemical composition of the ingredients, starter, grower, finisher diets (control diet) and supplementary feeds (SFI and SFII) was determined by the Association of German Agricultural Analytic and Research Institutes (VDLUFA) methods in accordance with Naumann and Bassler [26]. The DM content was determined mathematically by weighing before and after drying the samples at $103^{\circ} \mathrm{C}$. The muffle furnace was used to detect the crude ash content by weighing the samples before and after combustion at $600{ }^{\circ} \mathrm{C}$. The crude fat content was measured by the soxhlet apparatus using a standard protocol and the crude fibre content was determined by washing the samples in diluted acids and alkalis.

Moreover, the Dumas incineration method (Vario Max, Elementar, Analysensysteme GmbH, Langenselbold, Germany) was applied to measure the total N content. Sugar in the samples was analyzed by using the Luff-Schoorl method, while the atomic absorption spectrometry was used to analysed the minerals (Unicam Solaar 116, Thermo Fisher Scientific GmbH, Dreieich, Germany). Ion-exchange chromatography (AA analyzer LC 3000, Biotronic, Maintal, Germany) was used to analyse amino acid contents. Finally, a polarimetrical method was used to determine the starch content of the diets (Schmidt und Haensch GmbH \& Co., Berlin, Germany). Prior to formulating the experimental diets, the cereals were chemically analysed (Table 2). Diets were formulated to be iso-caloric and iso-nitrogenous (especially from 14 till $28 \mathrm{~d}$ of life), and the essential amino acids were calculated to be almost identical between all the diets, i.e., all experimental diets represented typical commercial formulations. 
Table 2. Nutrient contents of the experimental ingredients and diets ( $\mathrm{g} / \mathrm{kg} \mathrm{DM})$.

\begin{tabular}{cccccc}
\hline \multirow{2}{*}{ Item } & \multicolumn{2}{c}{ Ingredient } & & Feed & \\
\cline { 2 - 6 } & Crushed Corn & Squashed Rye & Control $^{\mathbf{1}}$ & SFI $^{\mathbf{2}}$ & SFII $^{\mathbf{3}}$ \\
\hline Dry matter & 897 & 893 & 879 & 880 & 879 \\
Crude ash & 16.9 & 17.7 & 45.7 & 48.5 & 48.8 \\
Crude protein & 105 & 104 & 222 & 238 & 238 \\
Crude fat & 66.6 & 19.8 & 67.7 & 61.5 & 69.8 \\
Crude fibre & 27.7 & 22.8 & 32.7 & 31.5 & 32.8 \\
Starch & 666 & 611 & 474 & 455 & 450 \\
Sugar & 26.9 & 61.8 & 41.7 & 43.4 & 42.8 \\
Nitrogen free extract & 784 & 836 & 632 & 621 & 611 \\
AMEn 4 MJ/kg & 15.4 & 13.3 & 14.2 & 14.0 & 14.1 \\
Calcium & 0.04 & 0.07 & 6.02 & 5.99 & 6.19 \\
Magnesium & 1.38 & 0.90 & 2.02 & 2.24 & 2.24 \\
Phosphorus & 3.81 & 2.77 & 5.60 & 5.97 & 6.00 \\
Sodium & 0.02 & 0.03 & 1.46 & 1.63 & 1.72 \\
Potassium & 4.64 & 5.26 & 7.70 & 8.69 & 8.69 \\
Chloride & 0.68 & 0.95 & 1.84 & 1.62 & 1.73 \\
Sulfur & 1.34 & 1.38 & 2.44 & 2.91 & 3.19 \\
Arginine & 4.86 & 5.29 & 13.9 & 14.7 & 14.8 \\
Cysteine & 2.41 & 2.52 & 4.14 & 4.16 & 4.16 \\
Isoleucine & 3.29 & 3.15 & 9.12 & 9.61 & 9.94 \\
Leucine & 12.3 & 6.34 & 16.6 & 17.3 & 17.8 \\
Lysine & 3.21 & 3.98 & 13.1 & 13.8 & 14.4 \\
Methionine & 2.16 & 1.77 & 7.31 & 7.11 & 7.51 \\
Phenylalanine & 4.93 & 4.48 & 10.6 & 11.2 & 11.6 \\
Threonine & 4.20 & 3.28 & 9.52 & 9.89 & 8.99 \\
Valine & 4.97 & 4.83 & 10.5 & 10.9 & 11.2 \\
\hline 1 Diet & & & & \\
\end{tabular}

\footnotetext{
${ }^{1}$ Diet containing (per kg): $9990 \mathrm{IU}$ vitamin A, $4995 \mathrm{IU}$ vitamin D3, $35 \mathrm{mg}$ vitamin E, $15.0 \mathrm{mg} \mathrm{Cu}, 20.0 \mathrm{mg} \mathrm{Fe}, 70.0 \mathrm{mg}$ Mn, $50.0 \mathrm{mg}$ Zn, $2.0 \mathrm{mg} \mathrm{I}, 0.25 \mathrm{mg}$ Se, 2160 U Endo 1,4 $\beta$ xylanase, 270 FTU 6-phytase, $70 \mathrm{mg}$ Na-salinomycin as coccidiostat. ${ }^{2,3}$ Supplementary feeds commercially produced for corn and rye and diet containing (per $\mathrm{kg}$ ): 11,100 IU vitamin A, $5550 \mathrm{IU}$ vitamin D3, $38 \mathrm{mg}$ vitamin E, $16.6 \mathrm{mg} \mathrm{Cu}, 22.2 \mathrm{mg} \mathrm{Fe}, 77.7 \mathrm{mg} \mathrm{Mn}, 55.5 \mathrm{mg} \mathrm{Zn}, 2.2 \mathrm{mg}$ I, $0.28 \mathrm{mg}$ Se, 2220 U Endo 1,4 $\beta$ xylanase, 277 FTU 6-phytase, $77.7 \mathrm{mg}$ Na-salinomycin as coccidiostat. ${ }^{4}$ Apparent metabolisable energy corrected for nitrogen balance, $\mathrm{AME}_{\mathrm{n}}(\mathrm{MJ} / \mathrm{kg})=0.1551 \times \%$ crude protein $+0.3431 \times \%$ crude fat $+0.1669 \times \%$ starch $+0.1301 \times \%$ sugar.
}

\subsection{Performance Parameters}

Individual body weight (BW) was measured weekly from $7 \mathrm{~d}$ of life by recording the wing number of each bird. At pen level, which corresponded to the replicate level, the feed intake and water intake were determined. The calculation of the feed conversion ratio (FCR) was based on the total feed intake and total body weight increase at pen level.

\subsection{Litter and Excreta Analyses}

To measure the DM content of the litter material, pooled samples were taken at 14, 21, 28, 35 and 41 days from three specified places in each pen. Additionally, a pooled fresh excreta sample $(\sim 60 \mathrm{~g})$ from each pen was collected at the same day of litter sampling to measure DM. A clean plastic bag was used for each pen on the litter surface until the required excreta amount was required. A part of the excreta sample was stored at $-20^{\circ} \mathrm{C}$ for viscosity measurement (modified in accordance with Dusel et al. [27]). At the end of the experiment, the manure in all pens was collected separately. To obtain a uniform sample, $\sim 10 \mathrm{~kg}$ manure from each pen was separated and homogenised to measure $\mathrm{DM}$ and nitrogen $(\mathrm{N})$ contents in the final litter. 


\subsection{Foot Pad Dermatitis (FPD) Scoring}

The foot pads (only the central plantar) of the birds were scored at 7, 14, 21, 28, 35 and 41 days on a scale from 0 to 7 in accordance with Mayne et al. [28]: score $0=$ healthy skin, score $7=$ more than $50 \%$ of foot pad area is necrotic (Figure 1). The average scoring of both legs was done for each bird.

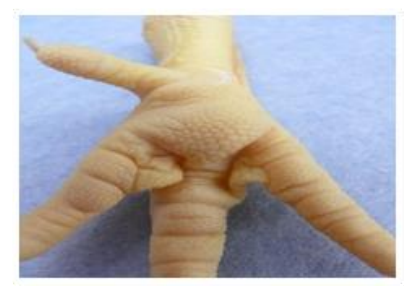

(a)

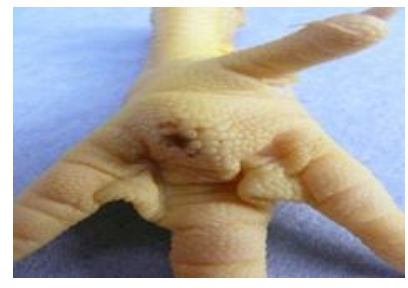

(b)

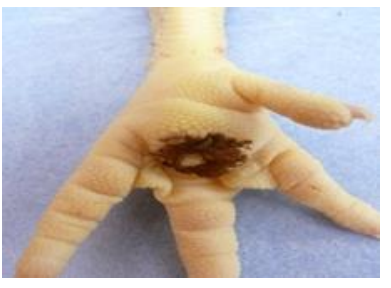

(c)

Figure 1. Scoring of foot pad: (a) Score $0=$ normal; (b) Score $3=$ small necrotic areas; (c) Score $7=>$ $50 \%$ of foot pad is necrotic (photo: ${ }^{(} \mathrm{Abd}$ El-Wahab, A./TiHo).

\subsection{Estimation of Nitrogen Efficiency}

For estimating the efficiency of nitrogen intake, all pens were used as an observation unit for evaluating nutrient efficiency between groups. The basis for consideration was the total feed intake in the pen, the body weight gain and the amount of final litter in the pen in accordance with Ullich et al. [29]. Briefly, to calculate the N-content in the fresh whole body of birds (including feathers), crude protein levels from previous publications were used [30,31]. From the means in $\mathrm{g}$ N/100 $\mathrm{g}$ fresh total body 3.31 [32], 3.02 [31], 2.75 [33] and 2.60 [30], a factor was derived (2.92) and used as the basis for calculations modified in accordance with Aletor et al. [31].

$$
\begin{gathered}
\text { N-retention efficiency }(\%)=g \text { N retained/g N consumed } \times 100 \\
\text { N-efficiency rate }=g \text { weight gain/g N consumed } \\
\text { N-excretion (apparent) }=\mathrm{g} \mathrm{N} \text { consumed-g N retained }
\end{gathered}
$$

\subsection{Dissection}

The dissection took place at $\mathrm{d} 42$ of life when 96 broilers ( $\mathrm{n}=3$ per replicate) were euthanised. The carcass, pancreas, gizzard, spleen, liver and bursa of Fabricius were excised and weighed. The carcass weight was done after removal of head, legs and all internal organs (except lung and kidney). Intestinal contents of the ileum were collected by gently finger stripping the intestinal segments. After collection, the fresh samples of ileum contents were stored at $-20{ }^{\circ} \mathrm{C}$ for analysis of viscosity. Samples of the ileum and caecum were taken for histological investigations, too.

\subsection{Digesta Viscosity}

The viscosity measurement was performed in accordance with Dusel et al. [27] with slight modification. Briefly, approximately $5 \mathrm{~g}$ of the stored excreta or ileal digesta were diluted with $20 \mathrm{~mL}$ distilled water then incubated for $30 \mathrm{~min}$ at about $40{ }^{\circ} \mathrm{C}$. Thereafter, the samples were centrifuged (9000 rpm) for $5 \mathrm{~min}$. The supernatant was obtained and about $600 \mu \mathrm{L}$ was used for viscosity by using a Brookfield viscometer (MODEL DV-II+VISCOSIMETER, Brookfield, 234 Engineering Laboratories Inc., Stoughton, MA, USA). The analysed samples and the viscometer cup were maintained at a temperature of $25-26{ }^{\circ} \mathrm{C}$ during viscosity measurements.

\subsection{Histological Investigations}

In order to determine the villus height, villus width and crypt depth in the ileum $(\sim 3 \mathrm{~cm}$ above the ileocaecal junction) and caecum (middle part), the histological samples were processed via a tissue 
sample of $\sim 2 \mathrm{~cm}$. The samples were washed firstly by phosphate-buffer saline, then fixed in $4 \%$ formaldehyde for $48 \mathrm{~h}$. Briefly, after fixation, samples were embedded in paraffin and $4-\mu \mathrm{m}$ sections of all samples were stained with haematoxylin and eosin (H\&E) using standard techniques in accordance with Slaoui and Fiette [34]. The villus height was measured from the tip of the villi to the villus crypt junction; villus width was measured at the base of the villus above the villus crypt junction; the depth of the crypts of Lieberkuhn was measured from the villus crypt junction to the basal lamina of the crypts (just above the Lamina muscularis mucosae). The relation of the villus height to the depth of the crypt was computed at the end. Measurements were performed using a Zeiss Axioscope (Carl Zeiss Jena GmbH, Jena, Germany).

\subsection{Statistical Analyses}

The statistical analysis was performed using the Statistical Analysis System for Windows the SAS ${ }^{\circledR}$ Enterprise Guide ${ }^{\circledR}$, version 9.3 (SAS Institute Inc., Cary, NC, USA). For all parameters, mean values, as well as the standard deviation of the mean, were calculated. Feed intake, water intake, the DM content, etc., were analysed at pen level. For parameters, like BW, ileal viscosity, FPD scores and the histological values the individual birds were the basis of the calculation. Data were analysed as $4 \times 1$ (4 different groups $\times$ effect of one factor "feed") factorial arrangement in a randomised complete block design. A Shapiro-Wilk test for normal distribution was performed and normally distributed data were checked for significant differences with the Ryan-Einot-Gabriel-Welsch-Test (simple Anova). The $p<0.05$ formed the basis of statistical significance for all statements concerning the results of the analysis.

\section{Results}

\subsection{Diets and Performance}

The results of the chemical analysis of the ingredients and experimental diets are presented in Table 2. The chemical analyses for both starter and grower diets are not shown (see Supplemental file). The analysed composition of crushed corn and squashed rye showed almost identical crude protein content (105 and $104 \mathrm{~g} / \mathrm{kg} \mathrm{DM}$, respectively). However, the apparent metabolisable energy (AMEn) $\mathrm{MJ} / \mathrm{kg}$ for crushed corn was slightly higher, (15.4) vs. (13.3), for squashed rye. The arginine, cysteine and lysine levels were slightly higher in the squashed rye than in crushed corn (Table 2). The crude protein levels in the SFI and SFII were higher $(238 \mathrm{~g} / \mathrm{kg} \mathrm{DM})$ compared to the control diet $(222 \mathrm{~g} / \mathrm{kg}$ $\mathrm{DM})$. The AMEn (MJ/kg) was comparatively similar for the finisher, SFI and SFII diets (14.1 \pm 0.13$)$.

Average performance parameters of all broilers during the experiment are presented in Table 3. The performance level of the broilers in the present study was high and exceeded the Ross 308 performance standards [35] except for the broilers in the mixed group. Body weight of the birds at $\mathrm{d}$ zero was $\sim 46 \mathrm{~g}$. At $\mathrm{d} 14$ of life, no significant differences in BW of broilers receiving the same grower diets were observed. Interestingly, no significant effect was observed regarding the increasing percentage of crushed corn or squashed rye in diets on BW weekly except at d 21 (Table 3). Differences in BW mainly arose between 14 and 21 days in the control group, with a significantly lower BW (1004 g) compared to groups fed SFI-Corn and SFII-Rye. Broilers fed a mixed diet exhibited the lowest BW ( $2899 \mathrm{~g})$ at $\mathrm{d} 42$ compared to the other experimental groups.

Results for feed intake, water intake, body weight gain (BWG) and FCR are presented in Table 4. No significant effects were noted between experimental diets' feed intake and water intake during the entire trial period ( $\mathrm{d} 14-\mathrm{d} 42)$. The water:feed intake ratio also showed no significant differences between all the experimental groups. BWG did not differ significantly between the experimental groups Although BWG for the control group was $\sim 5.65 \%$ higher than for birds in the mixed group the data showed no significant difference between the experimental groups. The control diet, however, tended to have a significantly more favourable FCR (1.60) compared to the other treatments, whereas 
the FCR was not significantly affected between groups fed SFI-Corn and SFII-Rye diets during the entire experimental period $(\mathrm{d} 14-\mathrm{d} 42)$.

Table 3. Average body weight $(\mathrm{g})$ of broilers from $\mathrm{d} 7$ to $\mathrm{d} 42$ of life (mean \pm SEM).

\begin{tabular}{|c|c|c|c|c|c|}
\hline \multirow{2}{*}{ Day of Life } & \multicolumn{4}{|c|}{ Experimental Diets } & \multirow{2}{*}{$p$-Value } \\
\hline & Control & SFI-Corn ${ }^{1}$ & SFII-Rye ${ }^{2}$ & Mixed & \\
\hline 7 & $219^{a} \pm 1.11$ & $224^{\mathrm{a}} \pm 1.65$ & $220^{\mathrm{a}} \pm 1.72$ & $221^{\mathrm{a}} \pm 2.03$ & 0.185 \\
\hline 14 & $534^{\mathrm{a}} \pm 1.97$ & $546^{\mathrm{a}} \pm 4.16$ & $532^{\mathrm{a}} \pm 7.63$ & $536^{\mathrm{a}} \pm 3.29$ & 0.186 \\
\hline 21 & $1004^{b} \pm 2.96$ & $1041^{\mathrm{a}} \pm 11.6$ & $1039^{a} \pm 7.68$ & $1027^{\mathrm{ab}} \pm 9.53$ & 0.018 \\
\hline 28 & $1646^{a} \pm 11.6$ & $1708^{a} \pm 25.7$ & $1658^{a} \pm 18.0$ & $1668^{a} \pm 19.1$ & 0.148 \\
\hline 35 & $2350^{\mathrm{a}} \pm 14.1$ & $2367^{\mathrm{a}} \pm 40.1$ & $2320^{a} \pm 26.7$ & $2338^{a} \pm 37.3$ & 0.761 \\
\hline 42 & $3038^{a} \pm 20.7$ & $2970^{a} \pm 51.3$ & $2932^{a} \pm 39.5$ & $2899^{\mathrm{a}} \pm 42.3$ & 0.106 \\
\hline
\end{tabular}

a,b Means within the same row with different superscripts differ significantly $(p<0.05) .{ }^{1,2}$ Supplementary feeds commercially produced for corn and rye.

Table 4. Feed intake, water intake, mean of body weight gain (BWG) and feed conversion ratio (FCR) of broilers during trial from 14 to $42 \mathrm{~d}$ (mean \pm SEM).

\begin{tabular}{cccccc}
\hline & \multicolumn{4}{c}{ Experimental Diets } & \multirow{2}{*}{ p-Value } \\
\cline { 2 - 5 } & Control & SFI-Corn ${ }^{\mathbf{1}}$ & SFII-Rye ${ }^{2}$ & Mixed & \\
\hline Feed intake (g) & $4008^{\mathrm{a}} \pm 60.5$ & $4039^{\mathrm{a}} \pm 86.7$ & $4089^{\mathrm{a}} \pm 76.5$ & $4083^{\mathrm{a}} \pm 58.9$ & 0.834 \\
Water intake (g) & $7012^{\mathrm{a}} \pm 106$ & $7113^{\mathrm{a}} \pm 122$ & $7462^{\mathrm{a}} \pm 144$ & $7107^{\mathrm{a}} \pm 252$ & 0.258 \\
W/F ratio ${ }^{3}$ & $1.75^{\mathrm{a}} \pm 0.04$ & $1.77^{\mathrm{a}} \pm 0.04$ & $1.83^{\mathrm{a}} \pm 0.02$ & $1.74^{\mathrm{a}} \pm 0.05$ & 0.466 \\
BWG (g) & $2504^{\mathrm{a}} \pm 20.6$ & $2424^{\mathrm{a}} \pm 48.3$ & $2400^{\mathrm{a}} \pm 40.7$ & $2363^{\mathrm{a}} \pm 40.6$ & 0.093 \\
FCR & $1.60^{\mathrm{c}} \pm 0.02$ & $1.67^{\mathrm{b}} \pm 0.01$ & $1.70^{\mathrm{a}, \mathrm{b}} \pm 0.01$ & $1.73^{\mathrm{a}} \pm 0.02$ & $<0.001$ \\
\hline a,b,c Means within the same row with different superscripts differ significantly $(p<0.05) .{ }^{1,2}$ Supplementary feeds \\
commercially produced for corn and rye. ${ }^{3}$ Water to feed intake ratio.
\end{tabular}

\subsection{Excreta Quality and Viscosity}

During the trial between days 14-35, there were no significant differences in the DM content of the excreta between the groups (Figure 2). The mean of excreta DM content for all experimental groups at d 35 was about $20.4 \% \pm 0.65$. However, excreta DM content $(18.3 \%)$ at d 41 was negatively affected by feeding SFII-Rye compared to broilers fed the control and SFI-Corn diets $(p<0.05)$. The viscosity of excreta analysed on a weekly basis is presented in Figure 2. Statistical analysis showed that the excreta viscosity did not differ significantly between the groups during the period between 14 and $41 \mathrm{~d}$. Interestingly, at $41 \mathrm{~d}$, birds fed the control or SFII-Rye diets had the highest excreta viscosity values ( $2.32 \mathrm{mPas})$ in comparison to those fed the SFI-Corn diet (2.29 mPas), however, this was not significant.
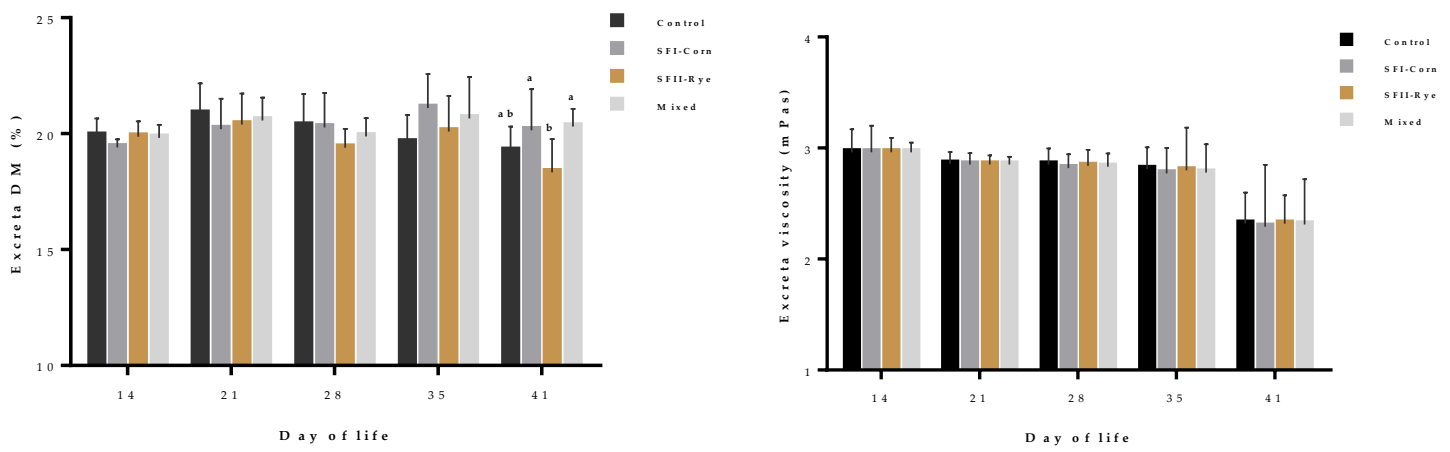

Figure 2. Dry matter (DM)-content and viscosity of excreta throughout the trial (d 14-d 41). ${ }^{a, b}$ Means at $\mathrm{d} 41$ for excreta DM with different superscripts differ significantly $(\mathrm{p}<0.05)$. 


\subsection{Litter Quality and FPD Scoring}

At the beginning of the trial ( $\mathrm{d} 14)$, the DM content of the litter was about $91.5 \%$. Litter DM content from 14 till $41 \mathrm{~d}$ was not significantly affected by the different experimental diets (Figure 3). The control group, however, had the driest litter $(47.7 \% \mathrm{DM})$ at $41 \mathrm{~d}$ of fattening. No significant differences in the FPD scores between the groups were noted (Figure 3). The FPD score with an average score of 1.49 for all groups (end of trial) was good overall, especially considering that scores below 2 are irrelevant from a veterinary point of view. Birds fed the SFII-Rye diet, nevertheless, had the lowest FPD scores (1.38) compared to the other groups.
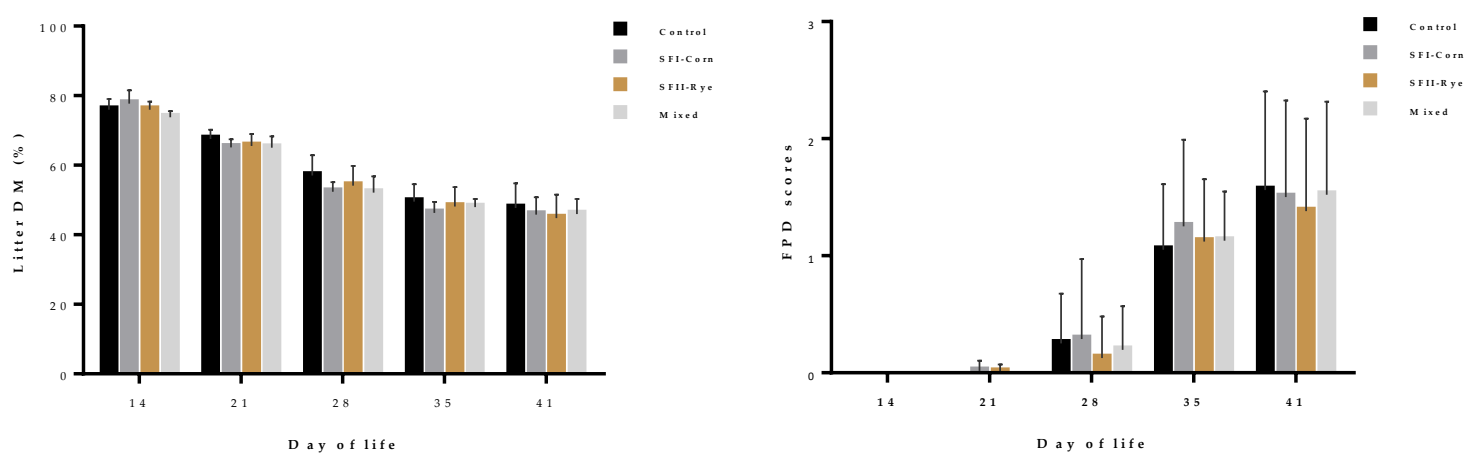

Figure 3. DM-content of litter material and foot pad scores during the trial (14-41 d).

Analysing the $\mathrm{N}$-content in the final total litter displayed no significant differences between the groups (Table 5). Additionally, the control group showed lower concentrations of N-retention efficiency $(p<0.001)$ compared to the other groups and, accordingly, the significantly highest absolute $\mathrm{N}$-excretion per pen or bird compared to the other groups. The N-retention efficiency in the group fed SFI-Corn was higher than in the other groups $(p<0.001)$.

Table 5. Estimations of balance and efficiency of nitrogen in litter for the entire trial period (d 14-d 42, mean \pm SEM).

\begin{tabular}{|c|c|c|c|c|c|}
\hline \multirow{2}{*}{ Parameter } & \multicolumn{4}{|c|}{ Experimental Diets } & \multirow{2}{*}{$p$-Value } \\
\hline & Control & SFI-Corn ${ }^{1}$ & SFII-Rye $^{2}$ & Mixed & \\
\hline Amount of litter/pen (kg) & $13.7^{\mathrm{a}} \pm 0.47$ & $13.8^{a} \pm 0.30$ & $14.8^{\mathrm{a}} \pm 0.21$ & $13.7^{a} \pm 0.30$ & 0.074 \\
\hline $\mathrm{N}$-intake from feed/pen $(\mathrm{g})$ & $1136^{\mathrm{a}} \pm 16.6$ & $945^{b} \pm 20.2$ & $963^{b} \pm 18.2$ & $959^{b} \pm 13.6$ & $<0.001$ \\
\hline $\begin{array}{c}\mathrm{N} \text {-content in final } \\
\text { litter/pen }(\mathrm{g})\end{array}$ & $297^{\mathrm{a}} \pm 22.1$ & $280^{\mathrm{a}} \pm 13.1$ & $304^{\mathrm{a}} \pm 18.0$ & $313^{\mathrm{a}} \pm 17.3$ & 0.629 \\
\hline Weight gain/pen $(\mathrm{g})$ & $20,032^{\mathrm{a}} \pm 165$ & $19,393^{a} \pm 387$ & $19,200^{a} \pm 326$ & $18,901^{\mathrm{a}} \pm 325$ & 0.093 \\
\hline N-retained/pen (g) & $708^{a} \pm 2.06$ & $654^{\mathrm{a}} \pm 12.0$ & $655^{\mathrm{a}} \pm 9.23$ & $637^{\mathrm{a}} \pm 9.87$ & 0.126 \\
\hline $\begin{array}{l}\text { N-retention efficiency } \\
(\mathrm{g} \mathrm{N} \text { retained/g N } \\
\text { consumed } \times 100)\end{array}$ & $62.3^{c} \pm 0.87$ & $69.2^{\mathrm{a}} \pm 0.49$ & $68.0^{b} \pm 0.62$ & $66.4^{b} \pm 0.56$ & $<0.001$ \\
\hline $\begin{array}{c}\text { N-efficiency ratio } \\
\text { (g weight gain/g N } \\
\text { consumed) }\end{array}$ & $17.6^{c} \pm 0.22$ & $20.5^{a} \pm 0.13$ & $19.9^{b} \pm 0.13$ & $19.7^{b} \pm 0.19$ & $<0.001$ \\
\hline $\begin{array}{c}\text { N-excretion } \\
\text { (apparent)/pen (g) }\end{array}$ & $429^{a} \pm 16.4$ & $291^{b} \pm 9.47$ & $308^{b} \pm 10.8$ & $322^{b} \pm 7.23$ & $<0.001$ \\
\hline $\begin{array}{l}\text { N-excretion } \\
\text { (apparent)/bird (g) }\end{array}$ & $55.3^{\mathrm{a}} \pm 2.04$ & $33.1^{b} \pm 1.18$ & $36.4^{\mathrm{b}} \pm 1.35$ & $36.9^{b} \pm 0.90$ & $<0.001$ \\
\hline
\end{tabular}

a,b,c Means within the same row with different superscripts differ significantly $(p<0.05) .{ }^{1,2}$ Supplementary feeds commercially produced for corn and rye. 


\subsection{Organ Weight and Ileal Viscosity}

The relative weights of some internal organs to live BW at $42 \mathrm{~d}$ are presented in Table 6. Compared to the control group, birds fed SFI-Corn displayed $(p=0.001)$ an increase in relative gizzard weight $(1.68$ vs. $1.34 \%)$. Nevertheless, the relative weights of other organs were not significantly affected by the dietary treatments. The viscosity of ileal digesta at $42 \mathrm{~d}$ analysed in selected treatments is also presented in Table 6. The results of the analysis showed no significant differences between the experimental groups concerning viscosity values.

Table 6. Effects of dietary treatments on results of slaughter analysis at $42 \mathrm{~d}$ (mean $\pm \mathrm{SEM}$ ).

\begin{tabular}{|c|c|c|c|c|c|}
\hline \multirow{2}{*}{ Item $(\%)$ of Live BW } & \multicolumn{4}{|c|}{ Experimental Diets } & \multirow{2}{*}{$p$-Value } \\
\hline & Control & SFI-Corn ${ }^{1}$ & SFII-Rye $^{2}$ & Mixed & \\
\hline Carcass weight & $83.4^{a} \pm 0.68$ & $81.1^{a} \pm 0.59$ & $81.0^{\mathrm{a}} \pm 0.70$ & $81.7^{a} \pm 0.81$ & 0.063 \\
\hline Pancreas & $0.17^{\mathrm{a}} \pm 0.01$ & $0.17^{\mathrm{a}} \pm 0.01$ & $0.19^{\mathrm{a}} \pm 0.01$ & $0.17^{\mathrm{a}} \pm 0.01$ & 0.085 \\
\hline Gizzard & $1.34^{b} \pm 0.05$ & $1.68^{a} \pm 0.05$ & $1.51^{\mathrm{ab}} \pm 0.004$ & $1.53^{\mathrm{a}} \pm 0.06$ & 0.001 \\
\hline Spleen & $0.10^{\mathrm{a}} \pm 0.004$ & $0.09^{\mathrm{a}} \pm 0.003$ & $0.10^{\mathrm{a}} \pm 0.004$ & $0.09^{\mathrm{a}} \pm 0.003$ & 0.042 \\
\hline Liver & $1.92^{\mathrm{a}} \pm 0.05$ & $1.99^{\mathrm{a}} \pm 0.05$ & $1.91^{\mathrm{a}} \pm 0.01$ & $1.89^{\mathrm{a}} \pm 0.04$ & 0.491 \\
\hline Bursa & $0.22^{\mathrm{a}} \pm 0.01$ & $0.21^{\mathrm{a}} \pm 0.01$ & $0.22^{\mathrm{a}} \pm 0.06$ & $0.20^{\mathrm{a}} \pm 0.01$ & 0.786 \\
\hline Ileal digesta viscosity (mPas) & $2.45^{\mathrm{a}} \pm 0.06$ & $2.41^{\mathrm{a}} \pm 0.08$ & $2.45^{\mathrm{a}} \pm 0.08$ & $2.44^{\mathrm{a}} \pm 0.08$ & 0.980 \\
\hline
\end{tabular}

${ }^{\mathrm{a}, \mathrm{b}}$ Means within the same row with different superscripts differ significantly $(p<0.05) .{ }^{1,2}$ Supplementary feeds commercially produced for corn and rye.

\subsection{Intestinal Morphology}

The results of the villus height, villus width, crypt depth and villus height/crypt depth ratio of the ileum and caecum at $42 \mathrm{~d}$ are presented in Table 7 and Figure 4. Birds fed SFI-Corn showed a lower ileal villus height $(425 \mu \mathrm{m})$ compared to other groups $(p=0.001)$. Villus width, crypt depth and villus height/crypt depth ratio of the ileum was not significantly affected between the groups. No significant differences were observed between the experimental groups for all morphological caecal parameters.

Table 7. Average villus height, villus width, crypt depth and villus height/crypt depth ratio in the ileum and caecum of broilers at $42 \mathrm{~d}$ (mean \pm SEM).

\begin{tabular}{|c|c|c|c|c|c|c|}
\hline \multirow{2}{*}{ Organ } & \multirow{2}{*}{ Parameter $(\mu \mathrm{m})$} & \multicolumn{4}{|c|}{ Experimental Diets } & \multirow{2}{*}{$p$-Value } \\
\hline & & Control & SFI-Corn ${ }^{1}$ & SFII-Rye ${ }^{2}$ & Mixed & \\
\hline \multirow{4}{*}{ Ileum } & Villus height & $483^{a} \pm 21.0$ & $425^{b} \pm 13.6$ & $518^{a} \pm 16.5$ & $512^{\mathrm{a}} \pm 15.0$ & 0.001 \\
\hline & Villus width & $113^{\mathrm{a}} \pm 3.91$ & $111^{\mathrm{a}} \pm 3.64$ & $123^{\mathrm{a}} \pm 3.59$ & $118^{\mathrm{a}} \pm 4.59$ & 0.133 \\
\hline & Crypt depth & $112^{\mathrm{a}} \pm 4.44$ & $104^{\mathrm{a}} \pm 3.81$ & $120^{\mathrm{a}} \pm 4.64$ & $119^{a} \pm 6.61$ & 0.096 \\
\hline & VH:CD ratio ${ }^{3}$ & $4.41^{\mathrm{a}} \pm 0.23$ & $4.16^{\mathrm{a}} \pm 0.15$ & $4.41^{\mathrm{a}} \pm 0.16$ & $4.45^{\mathrm{a}} \pm 0.15$ & 0.630 \\
\hline \multirow{4}{*}{ Caecum } & Villus height & $190^{a} \pm 9.64$ & $195^{a} \pm 5.69$ & $178^{a} \pm 6.57$ & $184^{\mathrm{a}} \pm 8.43$ & 0.462 \\
\hline & Villus width & $69.8^{a} \pm 3.51$ & $67.3^{a} \pm 2.08$ & $72.0^{\mathrm{a}} \pm 2.57$ & $76.3^{a} \pm 3.60$ & 0.199 \\
\hline & Crypt depth & $69.3^{a} \pm 3.85$ & $75.5^{\mathrm{a}} \pm 5.32$ & $71.8^{a} \pm 2.99$ & $82.1^{\mathrm{a}} \pm 4.92$ & 0.180 \\
\hline & VH:CD ratio ${ }^{3}$ & $2.82^{\mathrm{a}} \pm 0.14$ & $2.78^{a} \pm 0.15$ & $2.54^{\mathrm{a}} \pm 0.10$ & $2.38^{a} \pm 0.14$ & 0.079 \\
\hline
\end{tabular}

a,b Means within the same row with different superscripts differ significantly $(p<0.05) .{ }^{1,2}$ Supplementary feeds commercially produced for corn and rye. ${ }^{3}$ The ratio of villus height to crypt depth. 

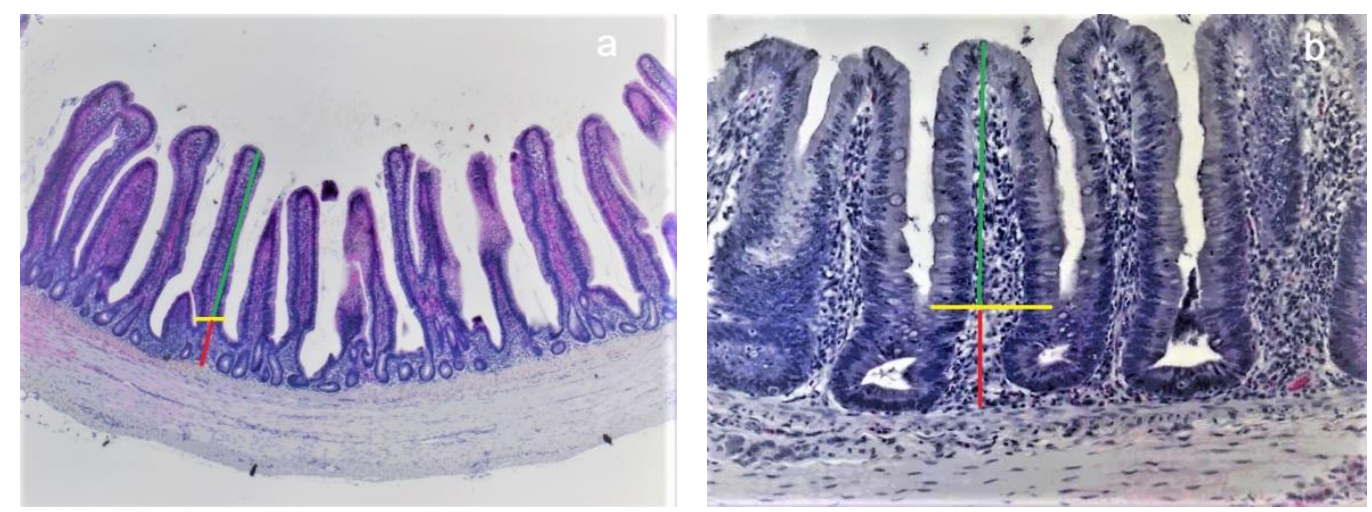

Figure 4. Example image: H\&E staining from the ileum (a) and caecum (b) intestinal wall, measuring lines included scale bar 200 and $50 \mu \mathrm{m}$, respectively. Green: villus height; yellow: villus width; red: crypt depth.

\section{Discussion}

Rye is a valuable grain, however, it still remains the most problematic cereal for broiler nutrition. Nevertheless, in the case of modern rye hybrids, this negative influence can be significantly reduced [6]. Moreover, the use of dietary structural components, such as coarse particles and whole grains in poultry diets, is currently common practice. In the present study, there were no losses from $14 \mathrm{~d}$ onwards and the average body weight of all groups was about $537 \mathrm{~g}$ at the beginning of the feeding experiment (14 d) and about $2959 \mathrm{~g}$ at the end of the trial $(42 \mathrm{~d})$, exceeding the available Ross 308 performance objectives of 519 and $2918 \mathrm{~g}$ [35] by about $1.39 \%$ at $42 \mathrm{~d}$. In general, the BW-gain (14-42 d) was higher in all groups ( $2422 \mathrm{~g}$ ) compared to the Ross 308 performance objectives $(2399 \mathrm{~g}$ ) by about $0.98 \%$. Interestingly, the feed intake between the treatments did not differ significantly. Our results are in agreement with the findings of Ghorbani et al. [36], who stated that a favoured feed intake was observed due to reduced digesta viscosity; consequently, a faster passage of the digesta was obtained.

In the current experiment, the BW and BWG were not negatively affected in broilers fed up to $30 \%$ rye diets in the final week, whereas only FCR worsened at the end of the trials. Nevertheless, the average FCR in the current experiment for all treatments was within the range from 1.60 to 1.73 (Ross 308 performance objectives from 14 till $42 \mathrm{~d}$ : FCR 1.73). In line with these results, Teirlynck et al. [15] did not find an impact of $5 \%$ rye inclusion in the diet of broilers from 1 to $42 \mathrm{~d}$. Similarly, during the grower-finisher rearing period in older broilers (22-42 d), no negative effects of rye grain on performance were found [7]. In the previous study of Arczewska-Wlosek et al. [7], all the birds were reared up to $42 \mathrm{~d}$ of age and fed with crumbled starter ( 1 to $21 \mathrm{~d}$ ) and pelleted grower-finisher diets ( 22 to $42 \mathrm{~d}$ ), with the rye grain being ground using a 5-mm sieve. In the current study, the inclusion of squashed rye into the diet started from $14 \mathrm{~d}$ at a percentage of only $5 \%$, the level being increased at a higher age ( $30 \%$ of squashed rye at $35 \mathrm{~d}$ ). Besides, the rye was only squashed (not ground), which might be less harmful to the animals compared to most of the previous studies, which provided rye-supplemented diets from $0 \mathrm{~d}$ onwards.

Moreover, the maximum level of rye in the current study amounted to $30 \%$, which is rather low compared to several other reported studies like Mourão and Pinheiro [37] and Józefiak et al. [38] who included $53 \%$ and $62 \%$ rye in the diets of broilers. The findings of other studies regarding the effects of dietary inclusion of rye on the performance in broilers are consistent. However, the extent of such adverse effects is not always the same, mainly depending on the chemical composition (NSP concentration) of the chosen rye variety. In the present study, the analysed total NSP content in rye was about $14.5 \% \mathrm{DM}$ and the concentration of total arabinoxylans in rye amounted to about $3.6 \% \mathrm{DM}$. Langhout [39] observed a 15\% decrease in BWG and a 13\% increase in FCR in broilers after inclusion of $25 \%$ rye in the diet (from 1 to $21 \mathrm{~d}$ ). Józefiak et al. [38] reported that feeding broilers with a diet containing $62 \%$ rye impaired growth performance indices compared to triticale- or wheat-based diets. 
Mourão and Pinheiro [37] observed decreased organic matter digestibility $(\sim 10 \%)$ and reduced BW $(\sim 9 \%)$ in broilers fed a diet containing 53\% rye. Tellez et al. [40] attributed the decrease in growth performance $(\sim 43 \%)$ in broilers fed a rye-based diet to an increase in gut viscosity. According to van Krimpen et al. [12], the inclusion of $10 \%$ rye in broilers diets from 14 to $28 \mathrm{~d}$ of life decreased performance compared to birds fed a diet containing $5 \%$ rye (1096 g for $10 \%$ rye vs. $1127 \mathrm{~g}$ for $5 \%$ rye at $21 \mathrm{~d} ; 1816 \mathrm{~g}$ vs. $1877 \mathrm{~g}$ at $28 \mathrm{~d}$ for $5 \%$ and $10 \%$, respectively). In the previous study by van Krimpen et al. [12], the broilers received a standard starter (0 to $14 \mathrm{~d}$ ) and finisher (29 to $35 \mathrm{~d}$ ) broiler diet, whereas during the grower period ( 15 to $28 \mathrm{~d}$ ), two experimental grower diets were provided with two increment levels $(5 \%$ and $10 \%)$ of rye inclusion being used. After pelletising, the starter diet was crumbled, whereas the grower and finisher diets were provided as pellets. In our study, the inclusion of rye was continuously used from 14 to $42 \mathrm{~d}$ of life with different levels. The use of whole cereals in poultry diets has become prevalent in several countries [41]. In our study, the squashed rye was added to the pellets, which, due to their physical structure, highly benefitted the animal performance/health. In the current study, however, no significant differences in final BW or BWG were noted when supplementing the grains (either corn or rye) with pellets compared to the control diet, but FCR was significantly low for the control diet. Published data on the effects on broiler performance, however, are contradictory. According to $\mathrm{Wu}$ et al. [42], feeding whole grain for broilers may influence the development of the gastrointestinal tract and, consequently, performance. Improved growth performance and feed efficiency with whole wheat feeding has been demonstrated in several reports $[18,43]$. Others have failed to show any advantage of including whole wheat in broiler diets [44,45]. According to Yasar [46], broilers fed up to $50 \%$ wheat during the finishing period had no significant differences in performance compared to the control diet due to the developed gastrointestinal system overcoming the detrimental effects of NSP.

Rye contains high concentrations of soluble carbohydrates (branched arabinoxylans) compared to other cereals such as corn or wheat [8]. Of special interest, in the current experiment, increasing dietary rye supplementation unexpectedly had no impact on the measured viscosity of excreta during the entire growing period or ileal digesta either. According to Yasar [46], broilers fed fine texture wheat produced significantly higher ileal viscosity than birds fed coarse wheat. The previous author believed that the release of NSP from the wheat grain into the lumen of the intestine may be greater for fine diets due to increased degradation of fine wheat particles, consequently forming a highly viscous digesta. Unfortunately, the level of NSP inside intestinal lumen was not determined in our study. Nevertheless, low ileal digesta viscosity in our study does not agree with the results of several previous studies aimed at evaluating the nutritional efficacy of rye in poultry diets. For instance, Dänicke et al. [47] found that the viscosity of ileal digesta was significantly increased in broilers fed a diet containing $56 \%$ rye. Lee et al. [48] found that a $40 \%$ inclusion rate of rye in broiler diets significantly enhanced the viscosity of jejunum and ileum digesta. In studies by Campbell et al. [49] and Choct et al. [50], the elevated levels of soluble NSP in rye increased the holding water in the digesta, consequently producing sticky droppings. Yasar [46] held another point of view, believing that the release of NSP from the wheat grain into the lumen of intestine may be greater for fine texture diets compared to coarse texture diets due to the increased degradation of fine wheat particles, resulting in a highly viscous digesta being formed.

According to Bedford and Classen [51], the presence of arabinoxylans increases digesta viscosity, affecting the availability and absorption of the nutrients. According to Smulikowska et al. [52] and Arczewska-Wlosek et al. [7], feeding young broilers rye-based diets led to high digesta viscosity, which may negatively affect the motility of the small intestine. Possibly, the specific conditions, e.g. increased level of new hybrid squashed rye at an older age, might explain the absence of dramatic increasing viscosity and/or reducing effects on performance in the current experiment. It should also be underlined that the chemical composition of cereals as wheat depends on growing location, use of fertiliser, temperature variations and moisture conditions [53]. Moreover, soluble NSP lowers the oxygen tension in the small intestine, hence encouraging the growth of some anaerobic microflora that 
can lead to production of short chain fatty acids and volatile fatty acids [54]. This might reflect the contrasts in viscosity and performance. Based on these findings, it can be concluded that up to $30 \%$ squashed rye inclusion at $42 \mathrm{~d}$ was not sufficient for creating substantial differences in digesta viscosity.

Nutrition is considered to be an important factor in the incidence and prevalence of FPD along with poor litter conditions. In the present study, no clinical problems concerning the foot pad health of the broilers could be determined independently of the experimental diets. Thus, the results of this study show neither negative nor positive effects of using the different dietary concepts. In contrast to the findings of Silva and Smithard [55], who stated that birds fed rye produced a very wet excreta, the litter DM was not affected, thereby reflecting the low FPD in the present study. Standing on wet litter brings the feet in constant contact with moisture and has been suggested to induce FPD $[28,56,57]$. Thus, these positive results of low FPD might be attributed to the good litter quality as well as to the comparable digesta viscosity between the treatments.

In the current study, the $\mathrm{N}$-content in the final litter did not differ significantly between all experimental groups at a comparable performance. However, there was a slight tendency $(p=0.629)$ of a higher N-content in the final litter in the mixed group than SFI-Corn of about $10.4 \%$. Interestingly, the protein content was higher in the control diet than the protein contents in other experimental treatments in the last two weeks of life (5th and 6 th) by about $4.74 \%$ and $10.8 \%$, respectively. The N-retention efficiency was increased by about $12.6 \%$ by feeding SFI-Corn diets than those fed the control diet due to adding the crushed corn to the pellets. The present data are in line with the results of Ullrich et al. [29], who were able to reduce the N-content in the final litter by about $28.4 \%$ by reducing the protein content intentionally in the starter, grower and finisher diets $(192,177$ and $170 \mathrm{~g} / \mathrm{kg} \mathrm{DM}$, respectively). Ospina-Rojas et al. [58] found a reduction in the N-content in the litter of about $32.4 \%$ when reducing the level of protein in the diet from $19 \%$ to $16 \%$ intentionally with a constant performance.

In the present study, $30 \%$ crushed grain increased relative gizzard weights by $14.6 \%$ compared to the control group. However, no significant effects were observed on the pancreas, spleen, liver and bursa weights between the experimental groups. Similarly, in an overview, Svihus [47] found that an average of $26.4 \%$ (range: $10-50 \%$ ) whole wheat addition increased relative gizzard weights by $38.7 \%$; however, responses ranged from 7 to $101 \%$. Nonetheless, it should be stressed that gizzard weight responses to whole grain inclusions are extremely inconsistent. The landmark response to whole grain feeding is increased relative gizzard weights. Ferket [47] described the gizzard as the 'pace-maker' of gut motility and reverse peristalsis in broilers. Birds have been found to naturally choose coarse feed particles which are thought to be responsible for a developed gizzard that ensures a complete grinding and a well-regulated digesta flow [20,21].

The results of the histological findings were done to verify whether inclusion of broken corn and/or squashed rye had a marked effect on intestinal morphology. The cereal type in feed had a major impact on the histological parameters of the intestine. In the current experiment, however, increased ileal villus length $(518 \mu \mathrm{m})$ and width $(123 \mu \mathrm{m})$ were observed at $42 \mathrm{~d}$ in birds fed rye diets. Based on these findings, it can be hypothesised that in those birds fed rye diets, the villi length increases, probably in an attempt to maintain nutrient absorption level by the villus length [12]. This hypothesis is supported by the findings in the current study. However, several authors observed similar or reduced villus length in broilers fed rye-based diets [15,59]. Smits and Annison [10] hypothesised that an increased viscosity of the ileal digesta due to the presence of soluble NSP might change the morphology of the villi. There have been a limited number of reports on the influence of feed particle size on intestinal morphology, and the results thereof are inconsistent. The present study showed that different dietary textures had no effect on the histological structure of the caecum and ileum (villus height, villus width, crypt depth) except for ileal villus height, a finding which is in accordance with Zang et al. [60], who reported a lack of gut morphology response to feed particle size. In contrast, Qaisrani et al. [61] reported greater duodenal villus height and lower crypt depth in broilers fed coarse rapeseed meal diets compared to those fed fine diets. Husvéth et al. [62] found no effect of whole wheat 
inclusion on villus size and crypt depth, suggesting that the beneficial effects of whole grain feeding are mediated more by higher digestive enzyme activities than the changes in the tissue structure of the gut.

\section{Conclusions}

In conclusion, it was possible, in this study, to include rye in broiler diets beginning with $5 \%$ in the third week of life, increasing to $30 \%$ of rye in the last weeks of the rearing period without compromising feed intake, performance, litter quality and foot pad health. It was also demonstrated that rye in squashed form is palatable, allowing the addition of rye to a pelleted supplementary feed. Thus, when a higher acreage of rye is intended for sustainability reasons, there are possibilities of using it in higher dietary levels if rye is fed in squashed form to pellet diets and at older age.

Supplementary Materials: The following are available online at http://www.mdpi.com/2071-1050/12/18/7753/s1, Table S1: Chemical composition of starter and grower diets.

Author Contributions: Conceptualisation, A.A.E.-W., C.V., V.T., R.G. and A.v.-F.; Methodology, A.A.E.-W., J.B.L., B.C., M.F.E.A., A.O., M.L., R.B. and C.V.; Validation, A.A.E.-W., M.L., R.B. and C.V.; Formal analysis, A.A.E.-W., J.B.L. and C.V.; Investigation, A.A.E.-W., M.L. and C.V.; Resources, R.B., V.T., R.G., A.v.F. and C.V.; Data curation, A.A.E.-W., J.B.L. and C.V.; Writing-original draft preparation, A.A.E.-W., J.B.L. and C.V.; Writing-review and editing, A.A.E.-W., J.B.L., B.C., M.F.E.A., A.O., M.L., V.T., R.B., R.G., A.v.-F., J.K. and C.V.; Visualisation, A.A.E.-W., M.L., R.B. and C.V; Supervision, C.V. and R.B.; Project administration, C.V.; Funding acquisition, C.V. All authors have read and agreed to the published version of the manuscript.

Funding: The study was financially supported by KWS LOCHOW GmbH, Bergen, Germany. The role of the funding body was merely financial for purchasing the materials and analysing the data for the trials at the Institute for Animal Nutrition, University of Veterinary Medicine Hannover, Foundation, Germany. It did not have any role in the collection, interpretation, analysis or writing of the data. This publication was supported by Deutsche Forschungsgemeinschaft and University of Veterinary Medicine Hannover, Foundation within the funding programme Open Access Publishing.

Acknowledgments: We would like to thank Frances Sherwood-Brock for proof-reading the manuscript to ensure correct English.

Conflicts of Interest: Venja Taube is an employee of BEST 3 Geflügelernährung GmbH, Twistringen, Germany. Richard Grone and Andreas von Felde are employees of KWS LOCHOW GmbH, Bergen, Germany. They had no role in the collection, analyses, or interpretation of data, nor in the writing of the manuscript or in the decision to publish the results. The manuscript has not been previously published.

\section{References}

1. Vaarst, M.; Steenfeldt, S.; Horsted, K. Sustainable development perspectives of poultry production. Worlds Poult. Sci. J. 2015, 71, 609-620. [CrossRef]

2. Alders, R.; Costa, R.; Gallardo, R.A.; Sparks, N.; Zhou, H. Smallholder poultry: Leveraging for sustainable food and nutrition security. In Encyclopedia of Food Security and Sustainability; Elsevier: Amsterdam, The Netherlands, 2018; pp. 340-346.

3. Spring, $P$. The challenge of cost effective poultry and animal nutrition: Optimizing existing and applying novel concepts. Lohmann Inf. 2013, 48, 38-46.

4. International Feed Industry Federation. 2016. Available online: http://www.ifif.org/ (accessed on 15 March 2020).

5. Chikmawati, T.; Gustafson, J.P. Rye (Secale cereale L.) and wheat (Triticum aestivum L.) simple sequence repeat variation within Secale spp.(Poaceae). HAYATI J. Biosci. 2013, 20, 163-170. [CrossRef]

6. Bederska-Łojewska, D.; Świątkiewicz, S.; Arczewska-Włosek, A.; Schwarz, T. Rye non-starch polysaccharides: Their impact on poultry intestinal physiology, nutrients digestibility and performance indices-A review. Ann. Anim. Sci. 2017, 17, 351-369. [CrossRef]

7. Arczewska-Wlosek, A.; Swiatkiewicz, S.; Bederska-Lojewska, D.; Orczewska-Dudek, S.; Szczurek, W.; Boros, D.; Fras, A.; Tomaszewska, E.; Dobrowolski, P.; Muszynski, S. The efficiency of xylanase in broiler chickens fed with increasing dietary levels of rye. Animals 2019, 9, 46. [CrossRef] [PubMed]

8. Bach Knudsen, K.E. Carbohydrate and lignin contents of plant materials used in animal feeding. Anim. Feed Sci. Technol. 1997, 67, 319-338. [CrossRef] 
9. Rodehutscord, M.; Rückert, C.; Maurer, H.P.; Schenkel, H.; Schipprack, W.; Bach Knudsen, K.E.; Schollenberger, M.; Laux, M.; Eklund, M.; Siegert, W. Variation in chemical composition and physical characteristics of cereal grains from different genotypes. Arch. Anim. Nutr. 2016, 70, 87-107. [CrossRef]

10. Smits, C.H.; Annison, G. Non-starch plant polysaccharides in broiler nutrition-towards a physiologically valid approach to their determination. Worlds Poult. Sci. J. 1996, 52, 203-221. [CrossRef]

11. Bedford, M.R.; Classen, H.L. Reduction of intestinal viscosity through manipulation of dietary rye and pentosanase concentration is effected through changes in the carbohydrate composition of the intestinal aqueous phase and results in improved growth rate and food conversion efficiency of broiler chicks. J. Nutr. 1992, 122, 560-569. [CrossRef]

12. Van Krimpen, M.; Torki, M.; Schokker, D. Effects of rye inclusion in grower diets on immune competence-related parameters and performance in broilers. Poult. Sci. 2017, 96, 3324-3337. [CrossRef]

13. Choct, M.; Annison, G. Anti-nutritive activity of wheat pentosans in broiler diets. Br. Poult. Sci. 1990, 31, 811-821. [CrossRef] [PubMed]

14. Bach Knudsen, K.E. Fiber and nonstarch polysaccharide content and variation in common crops used in broiler diets. Poult. Sci. 2014, 93, 2380-2393. [CrossRef] [PubMed]

15. Teirlynck, E.; Bjerrum, L.; Eeckhaut, V.; Huygebaert, G.; Pasmans, F.; Haesebrouck, F.; Dewulf, J.; Ducatelle, R.; Van Immerseel, F. The cereal type in feed influences gut wall morphology and intestinal immune cell infiltration in broiler chickens. Br. J. Nutr. 2009, 102, 1453-1461. [CrossRef] [PubMed]

16. Jürgens, H.-U.; Jansen, G.; Wegener, C.B. Characterisation of several rye cultivars with respect to arabinoxylans and extract viscosity. J. Agric. Sci. 2012, 4, 1-12. [CrossRef]

17. Schwarz, T.; Kuleta, W.; Turek, A.; Tuz, R.; Nowicki, J.; Rudzki, B.; Bartlewski, P.M. Assessing the efficiency of using a modern hybrid rye cultivar for pig fattening, with emphasis on production costs and carcass quality. Anim. Prod. Sci. 2015, 55, 467-473. [CrossRef]

18. Hetland, H.; Svihus, B.; Olaisen, V. Effect of feeding whole cereals on performance, starch digestibility and duodenal particle size distribution in broiler chickens. Br. Poult. Sci. 2002, 43, 416-423. [CrossRef]

19. Svihus, B. The gizzard: Function, influence of diet structure and effects on nutrient availability. Worlds Poult. Sci. J. 2011, 67, 207-224. [CrossRef]

20. Ferket, P.R.; Gernat, A.G. Factors that affect feed intake of meat birds: A review. Int. J. Poult. Sci. 2006, 5, 905-911.

21. Svihus, B.; Sacranie, A.; Denstadli, V.; Choct, M. Nutrient utilization and functionality of the anterior digestive tract caused by intermittent feeding and inclusion of whole wheat in diets for broiler chickens. Poult. Sci. 2010, 89, 2617-2625. [CrossRef]

22. Amerah, A. Interactions between wheat characteristics and feed enzyme supplementation in broiler diets. Anim. Feed Sci. Tech. 2015, 199, 1-9. [CrossRef]

23. Stilling, R.M.; van de Wouw, M.; Clarke, G.; Stanton, C.; Dinan, T.G.; Cryan, J.F. The neuropharmacology of butyrate: The bread and butter of the microbiota-gut-brain axis? Neurochem. Int. 2016, 99, 110-132. [CrossRef] [PubMed]

24. Choct, M.; Dersjant-Li, Y.; McLeish, J.; Peisker, M. Soy oligosaccharides and soluble non-starch polysaccharides: A review of digestion, nutritive and anti-nutritive effects in pigs and poultry. Asian Austral. J. Anim. Sci. 2010, 23, 1386-1398. [CrossRef]

25. Abd El-Wahab, A.; Visscher, C.; Kamphues, J. Impact of different dietary protein sources on performance, litter quality and foot pad dermatitis in broilers. J. Anim. Feed Sci. 2018, 27, 148-154. [CrossRef]

26. Naumann, C.; Bassler, R. Methoden der Landwirtschaftlichen Forschungs-und Untersuchungsanstalt, Biochemische Untersuchung von Futtermitteln. Methodenbuch III (Einschließlich der Achten Ergänzungen); VDLUFA: Darmstadt, Germany, 2012.

27. Dusel, G.; Kluge, H.; Glaser, K.; Simon, O.; Hartmann, G.; Lengerken, J.; Jeroch, H. An investigation into the variability of extract viscosity of wheat-relationship with the content of non-starch-polysaccharide fractions and metabolisable energy for broiler chickens. Arch. Anim. Nutr. 1997, 50, 121-135. [CrossRef]

28. Mayne, R.K.; Else, R.W.; Hocking, P.M. High litter moisture alone is sufficient to cause footpad dermatitis in growing turkeys. Br. Poult. Sci. 2007, 48, 538-545. [CrossRef]

29. Ullrich, C.; Langeheine, M.; Brehm, R.; Taube, V.; Siebert, D.; Visscher, C. Influence of reduced protein content in complete diets with a consistent arginine-lysine ratio on performance and nitrogen excretion in broilers. Sustainability 2018, 10, 3827. [CrossRef] 
30. Bregendahl, K.; Sell, J.; Zimmerman, D. Effect of low-protein diets on growth performance and body composition of broiler chicks. Poult. Sci. 2002, 81, 1156-1167. [CrossRef]

31. Aletor, V.A.; Hamid, I.I.; Niess, E.; Pfeffer, E. Low-protein amino acid-supplemented diets in broiler chickens: Effects on performance, carcass characteristics, whole-body composition and efficiencies of nutrient utilisation. J. Sci. Food Agric. 2000, 80, 547-554. [CrossRef]

32. Ernährungsphysiologie, G.F. Empfehlungen zur Energie und Nährstoffversorgung der Legehennen und Masthühner (Broiler); DLG Verlag: Frankfurt am Main, Germany, 1999.

33. Kamran, Z.; Sarwar, M.; Nisa, M.; Nadeem, M.; Ahmad, S.; Mushtaq, T.; Ahmad, T.; Shahzad, M. Effect of lowering dietary protein with constant energy to protein ratio on growth, body composition and nutrient utilization of broiler chicks. Asian Australas. J. Anim. Sci. 2008, 21, 1629-1634. [CrossRef]

34. Slaoui, M.; Fiette, L. Histopathology procedures: From tissue sampling to histopathological evaluation. In Drug Safety Evaluation; Springer: Berlin/Heidelberg, Germany, 2011; pp. 69-82.

35. Aviagen. Ross 308: Broiler Nutrition Specifications 2019. Available online: http://en.aviagen.com/assets/ Tech_Center/Ross_Broiler/RossBroilerNutritionSpecs2019-EN.pdf (accessed on 24 March 2020).

36. Ghorbani, M.; Fayazi, J.; Chaji, M. Effect of dietary phytase and NSP-degrading enzymes in diets containing rape seed meal on broiler performance and carcass characteristic. Res. J. Biol. Sci. 2009, 4, 258-264.

37. Mourão, J.L.T.d.A.M.; Pinheiro, V.M.C. Effects of rye, wheat and xylanase supplementation on diet nutritive value and broiler chicken performance. Rev. Bras. Zootec. 2009, 38, 2417-2424. [CrossRef]

38. Jozefiak, D.; Rutkowski, A.; Jensen, B.B.; Engberg, R.M. Effects of dietary inclusion of triticale, rye and wheat and xylanase supplementation on growth performance of broiler chickens and fermentation in the gastrointestinal tract. Anim. Feed Sci. Tech. 2007, 132, 79-93. [CrossRef]

39. Langhout, D.J. The Role of the Intestinal Flora as Affected by Non-Starch Polysaccharides in Broiler Chicks; Agricultural University Wageningen: Wageningen, The Netherlands, 1998.

40. Tellez, G.; Latorre, J.D.; Kuttappan, V.A.; Kogut, M.H.; Wolfenden, A.; Hernandez-Velasco, X.; Hargis, B.M.; Bottje, W.G.; Bielke, L.R.; Faulkner, O.B. Utilization of rye as energy source affects bacterial translocation, intestinal viscosity, microbiota composition, and bone mineralization in broiler chickens. Front. Genet. 2014, 5. [CrossRef] [PubMed]

41. Singh, Y. Whole Grain Inclusion in Poultry Diets: Effects on Performance, Nutrient Utilisation, Gut Development, Caecal Microflora Profile and Coccidiosis Challenge. Ph.D. Thesis, Massey University, Palmerston North, New Zealand, 2013.

42. Wu, Y.B.; Ravindran, V.; Thomas, D.; Birtles, M.; Hendriks, W. Influence of method of whole wheat inclusion and xylanase supplementation on the performance, apparent metabolisable energy, digestive tract measurements and gut morphology of broilers. Br. Poult. Sci. 2004, 45, 385-394. [CrossRef] [PubMed]

43. Svihus, B.; Hetland, H. Ileal starch digestibility in growing broiler chickens fed on a wheat-based diet is improved by mash feeding, dilution with cellulose or whole wheat inclusion. Br. Poult. Sci. 2001, 42, 633-637. [CrossRef] [PubMed]

44. Jones, G.; Taylor, R. The incorporation of whole grain into pelleted broiler chicken diets: Production and physiological responses. Br. Poult. Sci. 2001, 42, 477-483. [CrossRef] [PubMed]

45. Bennett, C.; Classen, H.; Riddell, C. Feeding broiler chickens wheat and barley diets containing whole, ground and pelleted grain. Poult. Sci. 2002, 81, 995-1003. [CrossRef] [PubMed]

46. Yasar, S. Performance, gut size and ileal digesta viscosity of broiler chickens fed with a whole wheat added diet and the diets with different wheat particle sizes. Int. J. Poult. Sci. 2003, 2, 75-82.

47. Dänicke, S.; Simon, O.; Jeroch, H. Effects of dietary fat type and non-starch-polysaccharide-hydrolysing enzyme addition to rye-based diets on muscle protein turnover in broilers. Br. Poult. Sci. 2003, 44, 245-255. [CrossRef]

48. Lee, K.; Everts, H.; Kappert, H.; Van Der Kuilen, J.; Lemmens, A.; Frehner, M.; Beynen, A. Growth performance, intestinal viscosity, fat digestibility and plasma cholesterol in broiler chickens fed a rye-containing diet without or with essential oil components. Int. J. Poult. Sci. 2004, 3, 613-618.

49. Campbell, G.; Classen, H.; Reichert, R.; Campbell, L. Improvement of the nutritive value of rye for broiler chickens by gamma irradiation-induced viscosity reduction. Br. Poult. Sci. 1983, 24, 205-212. [CrossRef] [PubMed] 
50. Choct, M.; Hughes, R.J.; Trimble, R.P.; Angkanaporn, K.; Annison, G. Non-starch polysaccharide-degrading enzymes increase the performance of broiler chickens fed wheat of low apparent metabolizable energy. J. Nutr. 1995, 125, 485-492. [CrossRef] [PubMed]

51. Bedford, M.; Classen, H. An in vitro assay for prediction of broiler intestinal viscosity and growth when fed rye-based diets in the presence of exogenous enzymes. Poult. Sci. 1993, 72, 137-143. [CrossRef]

52. Smulikowska, S.; Mieczkowska, A.; Nguyen, C.; Babelewska, M. The influence of digesta viscosity on the development of the stomach, on in vitro small intestinal motility, and on digestion of nutrients in broiler chickens. J. Anim. Feed Sci. 2002, 11, 683-694. [CrossRef]

53. Ravindran, V.; Amerah, A.M. Wheat: Composition and feeding value for poultry. In Soybean and Wheat Crops: Growth, Fertilization and Yield; Nova Science Publishers: New York, NY, USA, 2009; pp. 245-259.

54. Simon, O. The mode of action of NSP hydrolysing enzymes in the gastrointestinal tract. J. Anim. Feed Sci. 1998, 7, 115-123. [CrossRef]

55. Silva, S.; Smithard, R. Effect of enzyme supplementation of a rye-based diet on xylanase activity in the small intestine of broilers, on intestinal crypt cell proliferation and on nutrient digestibility and growth performance of the birds. Br. Poult. Sci. 2002, 43, 274-282. [CrossRef]

56. Abd El-Wahab, A.; Visscher, C.; Beineke, A.; Beyerbach, M.; Kamphues, J. Effects of high electrolyte contents in the diet and using floor heating on development and severity of foot pad dermatitis in young turkeys. J. Anim. Physiol. Anim. Nutr. 2013, 97,39-47. [CrossRef]

57. Chuppava, B.; Visscher, C.; Kamphues, J. Effect of different flooring designs on the performance and foot pad health in broilers and turkeys. Animals 2018, 8, 70. [CrossRef]

58. Ospina-Rojas, I.; Murakami, A.; Duarte, C.; Eyng, C.; Oliveira, C.; Janeiro, V. Valine, isoleucine, arginine and glycine supplementation of low-protein diets for broiler chickens during the starter and grower phases. Br. Poult. Sci. 2014, 55, 766-773. [CrossRef]

59. Mathlouthi, N.; LalleȲs, J.P.; Lepercq, P.; Juste, C.; Larbier, M. Xylanase and $\beta$-glucanase supplementation improve conjugated bile acid fraction in intestinal contents and increase villus size of small intestine wall in broiler chickens fed a rye-based diet. J. Anim. Sci. 2002, 80, 2773-2779. [CrossRef]

60. Zang, J.J.; Piao, X.S.; Huang, D.S.; Wang, J.J.; Ma, X.; Ma, Y.X. Effects of feed particle size and feed form on growth performance, nutrient metabolisability and intestinal morphology in broiler chickens. Asian-Australas J. Anim. Sci. 2009, 22, 107-112. [CrossRef]

61. Qaisrani, S.; Van Krimpen, M.; Kwakkel, R.; Verstegen, M.; Hendriks, W. Diet structure, butyric acid, and fermentable carbohydrates influence growth performance, gut morphology, and cecal fermentation characteristics in broilers. Poult. Sci. 2015, 94, 2152-2164. [CrossRef] [PubMed]

62. Husvéth, F.; Pál, L.; Galamb, E.; Ács, K.; Bustyaházai, L.; Wágner, L.; Dublecz, F.; Dublecz, K. Effects of whole wheat incorporated into pelleted diets on the growth performance and intestinal function of broiler chickens. Anim. Feed Sci. Tech. 2015, 210, 144-151. [CrossRef]

(C) 2020 by the authors. Licensee MDPI, Basel, Switzerland. This article is an open access article distributed under the terms and conditions of the Creative Commons Attribution (CC BY) license (http://creativecommons.org/licenses/by/4.0/). 